\title{
INTERNATIONAL COMMERCIAL ARBITRATION PUT TO THE TEST IN THE COMMONWEALTH
}

\section{Petra Butler*}

The article discusses the Commonwealth Study on international commercial arbitration conducted in 2019. The importance of the availability of international commercial arbitration as a dispute resolution mechanism lies in the link between trade and the accessibility of a dispute resolution mechanism that reflects the needs of cross-border trade. Given that the Commonwealth has a unique legal and trade ecosystem the Study provides a rare opportunity to consider what a best practice modern international commercial arbitration framework should look like to encourage cross-border trade.

* Professor, Victoria University of Wellington, Faculty of Law; and Director, Institute of Small and Micro States. The article is based on A Study of International Commercial Arbitration in the Commonwealth (The Commonwealth Secretariat, 2020) [The Study] which was led by the Commonwealth's Office of Civil and Criminal Justice Reform. An expert group, consisting of Funke Adekoya SAN, Gary Born, Robert Griffiths QC, Audley Sheppard QC and led by the author, supported the Commonwealth Office. Dharshini Prasad served as the Executive Secretary to the expert group. The International Arbitration group at Wilmer Cutler Pickering Hale and Dorr LLP provided technical assistance to the Commonwealth. The expert group was further assisted by a task force comprised of international arbitration, trade and capacity building specialists representing the different regions of the Commonwealth (Professor Anthony Daimsis, University of Ottawa; Tejas Karia, partner, Shardul Amarchand Mangaldas \& Co, New Delhi; Dr Emilia Onyema, School of Oriental and African Studies, London; Nania Owusu-Anomah Sackey, Bentsi-Enchill, Accra; Mahesh Rai, director, dispute resolution, Drew \& Napier LLC, Singapore; Dr Jan Yves Remy, deputy-director, Shridrath Ramphal Centre, University of the West Indies, Cave Hill Campus; Kamal Shah, partner, Stephenson Harwood LLP, London; Ana Tuiketei, barrister, Suva). The Study employed a mixed blackletter law, law in context and comparative law analysis. In addition to relying on available literature the study compiled a country report for each of the Commonwealth 54 jurisdictions (the United Kingdom was divided into England, Wales \& Northern Ireland and Scotland) that outlines the country's international commercial arbitration landscape. To gain a further insight into the attitude towards international commercial arbitration and the challenges it faces, eight stakeholder surveys were conducted (arbitrator; counsel; businesses; arbitral institutions; academics; the judiciary; students; and governments) which received 653 responses and 65 interviews held with international commercial arbitration and commodity arbitration specialists throughout the Commonwealth. The Study was conducted between January and August 2019. The Study was first discussed by the author in an article published in the ICC Institute of World Business Law Newsletter, Issue 13, 2019. The author would like to thank everyone involved in the Study for their enthusiasm and support and WilmerHale for providing technical assistance. 


\section{INTRODUCTION}

The recent COVID-19 pandemic $^{2}$ has had an unprecedented impact on businesses trading crossborder due to restrictions which made it often impossible or at least extremely difficult for businesses to fulfil their contractual obligations. ${ }^{3}$ A survey of New Zealand law firms shows that client alerts have advised on the contract law paradigms available to businesses should their contract be disrupted by COVID-19. ${ }^{4}$ However, having a contractual remedy or a defence against the contractual claim of the other party to the contract is only one of the requirements to deal successfully with the fall out arising out of a contract tainted by COVID-19. A good remedy or a valid defence is not worth much if the party is not able to assert its rights. A dispute resolution mechanism that best allows the party to assert its rights is a vital ingredient to a successful claim or defence.

Alongside cross-border litigation, international commercial mediation and negotiation, international commercial arbitration is part of the canon of dispute resolution mechanisms available to businesses when faced with a cross-border dispute. ${ }^{5}$ At this point in time it is heralded as the mechanism fitting best the business needs of cross-border trade. It is seen, in particular, as providing access to effective cross-border commercial justice due to it being neutral, efficient, expert, final and enforceable. Statistics evidence that international commercial arbitration is the preferred mechanism for the resolution of cross-border disputes among Fortune 500 companies $^{6}$ and the preferred dispute

1 COVID-19, an abbreviation for "Coronavirus disease 2019", is an infectious disease caused by severe acute respiratory syndrome coronavirus 2 (SARS-CoV-2). See World Health Organization Origin of SARS-CoV-2 (26 March 2020)

2 COVID-19 was declared a pandemic by the Director-General of the World Health Organization, Dr Tedros Adhanom Ghebreyesus, on 11 March 2020 due to the rapid increase in the number of cases outside China since the end of February 2020: see World Health Organization "WHO announces Covid-19 outbreak a pandemic" (12 March 2020) <www.euro.who.int/en/health-topics>.

3 See regarding the issue of force majeure and hardship arising in regard to the inability to fulfil contractual obligations due to COVID-19: Laura Maria Franciosi "The Effects of COVID-19 on International Contracts: A Comparative Overview" (2020) 51 VUWLR 413, also in this issue.

4 See for example Simpson Grierson "Covid-19 force majeure checklist - when can businesses trigger this provision?" (31 March 2020) <www.simpsongrierson.com/articles>; Chapman Tripp "COVID-19 and contractual obligations" (3 April 2020) <www.chapmantripp.com/publications>; David Friar and Simone Cooper "COVID-19 Will the effects of the coronavirus allow you to avoid contractual obligations?" (6 March 2020) Bell Gully <www.bellgully.com/publications>; and Will Iriving and Gordon Lamb "Coronavirus contractual performance amidst a global outbreak" (20 February 2020) Russell McVeagh <www.russellmcveagh.com/insights>.

5 See a detailed discussion and comparison to cross-border litigation and international commercial meditation in Commonwealth Secretariat International Commercial Arbitration Study (forthcoming) at [40] and following.

6 White \& Case and Queen Mary University of London School of International Arbitration 2018 International Arbitration Survey: The Evolution of International Arbitration (2018) [2018 QM Study]. It has to be noted that according to the study's methodology section business involvement was through in-house counsel. 
resolution mechanism in the commodity trade and in maritime matters. ${ }^{7}$ Furthermore, recent research into the dispute risk management needs of small and medium-sized enterprises (SMEs) suggests that international commercial arbitration will be able to fulfil the SMEs' cross-border dispute resolution needs to a greater extent than the current default mechanism of cross-border litigation. ${ }^{8}$ And where there are industry specific arbitration practices and communities, international commercial arbitration offers the benefit of trade specialists (whether lawyers or otherwise) that are familiar with the trade resolving disputes specific to that trade.

The importance of international commercial arbitration as an available dispute resolution mechanism is highlighted by the current pandemic but is by no means a current issue. The advantages of international commercial arbitration mentioned in the previous paragraph were acknowledged by the Senior Officials of Commonwealth Law Ministries at their meeting in London in October 2018. The Officials requested the Commonwealth Secretariat to conduct a study: ${ }^{9}$

\footnotetext{
... to understand the use of international commercial arbitration in addressing commercial disputes across the Commonwealth, as well as ways in which member countries may strengthen the accessibility and effectiveness of international commercial arbitration.
}

The findings of this study (the Study) are the focus of this article because it provides the rare opportunity to assess the state of international commercial arbitration in a unique ecosystem and to draw lessons for the use of international commercial arbitration as a cross-border dispute resolution mechanism. The lessons learned are important since a best practice international commercial arbitration framework has to be part of the resilience structure of any country to help its business community to withstand disruptions such as COVID-19. ${ }^{10}$

The article will firstly outline the context to the Study in Part II and then set out the challenges the Commonwealth faces regarding a robust modern international arbitration framework that

7 See the Federation of Oils, Seeds and Fats Associations (FOSFA); the Grain and Feed Trade Association (GAFTA); the International Cotton Association (ICA); the London Metal Exchange (LME); the British Coffee Association (BCA); and the Refined Sugar Association (RSA). See also LexisPSL Commodities arbitration-trade associations and arbitration rules (2019).

8 See Petra Butler and Georgia Whelan "Does the dispute resolution regime in Europe really serve MSMEs?" in Nikos Lavranos and Jóse Rafael Mata Dona (eds) International Arbitration and EU Law (Edward Elgar) (forthcoming).

9 The Commonwealth "Commonwealth International Arbitration Study" <https://thecommonwealth.org/ arbitration-study>.

10 Regarding a discussion of the importance and the advantages of international commercial arbitration see Petra Butler and Campbell Herbert "Access to Justice vs Access to Justice for Small and Medium-Sized Enterprises: The Case For A Bilateral Arbitration Treaty" (2014) 26 NZULR 186; Tibor Várady and others International Commercial Arbitration: A Transnational Perspective (6th ed, West Academic Publishing, Saint Paul (Min), 2015) at 1; and Gary B Born International Commercial Arbitration (2nd ed, Wolters Kluwer, Alphen aan den Rijn (The Netherlands), 2014) vol 1 at 93. 
incorporates best practice in Part III. Lastly Part IV will explore some of the solutions open to the Commonwealth to improve the international commercial arbitration framework within its borders and to take advantage of its unique ecosystem.

\section{THE COMMONWEALTH}

The Commonwealth is a voluntary association of 53 independent countries, ${ }^{11}$ comprising large and small, developed and developing, landlocked and island economies. In fact, 31 member states are classified as small states. Small states are generally states with a population of 1.5 million or less. However, the Commonwealth does include larger states in the small state's definition that share similar characteristics with small states. ${ }^{12}$ The Commonwealth is home to about 2.4 billion people of which about 91 per cent live in Asia and Africa combined. ${ }^{13}$

What makes the Commonwealth unique is that vastly diverse countries representing nearly all corners of the world and a multitude of cultures are bound under the Commonwealth umbrella of a shared heritage, historical trade ties, familiar administrative and legal systems, and the use of predominantly one language, English, as a means of communication in trade and political discourse. Hence the Commonwealth represents a unique platform to advance and to realise not only common values but also common goals.

In April 2018 the Commonwealth Heads of Government recognised "international trade and investment as an engine for generating inclusive and participative economic growth and a means to deliver the 2030 Agenda for Sustainable Development" as a common goal. ${ }^{14}$ The Commonwealth countries need to ensure a continuous increase in trade, development and resilience against global economic crises to be able to harness the distinctive Commonwealth advantage now and in the future

11 In addition to the 53 independent members, the Commonwealth also comprises associated and overseas territories which are formally governed by the United Kingdom, Australia, or New Zealand or linked to these member states but are self-governing. The people of these associated states are regarded as part of the Commonwealth family and are eligible to take part in many activities. Some of these associated states include Anguilla, Bermuda, British Antarctic Territory, British Indian Ocean Territory, British Virgin Islands, Cayman Islands, Cook Islands, Falkland Islands and Norfolk Island.

12 The Commonwealth Small States and the Commonwealth: Supporting Sustainable Development (Commonwealth Secretariat, 2017) at 1.

13 Central Intelligence Agency "The World Fact Book, Guide to Country Comparisons" <www.cia.gov/library>.

14 Commonwealth Heads of Government Declaration on the Commonwealth Connectivity Agenda for Trade and Investment (20 April 2018). The Commonwealth Heads of Government committed themselves to the goal of increasing intra-Commonwealth trade to USD 2 Trillion by 2030 and expanding intra-Commonwealth investment. To achieve this goal, they adopted a six point connectivity agenda to boost trade and investment links across the Commonwealth. New Zealand's two-way trade with the Commonwealth has amounted to NZD 52.69 billion in the year 2019/2020 compared to the NZD 32.84 billion two-way trade with China, New Zealand's largest single trading partner. 
and to deliver on the sustainable development goals (SDGs). ${ }^{15}$ The continuing increase in trade and development and the strengthening of resilience rests, inter alia, on two important pillars: attraction of foreign direct investment and the cross-border trade of the countries' own businesses. Regarding the latter it is in particular SMEs that need to participate in the intra- Commonwealth and global trade to drive economic growth. ${ }^{16}$ Notwithstanding the importance of SMEs, in reality - and in contrast to large businesses and multinationals - the majority of SMEs generally do not engage in cross-border trade. ${ }^{17}$ As a result, a significant source of economic growth remains unexploited. It is therefore crucial to eliminate or significantly reduce the trade barriers specifically for SMEs - those include the misconception and unfamiliarity with cross-border dispute resolution. ${ }^{18}$

The second pillar, the attraction of foreign direct investment, is one of the key concerns of the Commonwealth Connectivity Agenda for Trade and Investment. ${ }^{19}$ Sustained foreign direct

15 Compare Commonwealth Heads of Government, above n 14. See Jeffrey A Frankel and David Romer "Does trade cause growth?" (1999) 89 Am Econ Rev 379; Fransisco Alcalá and Antonio Ciccone "Trade and Productivity" (2004) 119 Q J Econ 613; Pam Zahonogo "'Trade and economic growth in developing countries: Evidence from sub-Saharan Africa"' (2016) 3 Journal of African Trade 41; and HG Johnson International Trade and Economic Growth: Studies in Pure Theory (Allen \& Unwin, London, 1958).

16 What constitutes a small and medium-sized enterprise (SME) is generally defined by the number of employees. How many employees constitute a large enterprise is different from country to country (for example SMEs in New Zealand are businesses with less than 70 employees whereas in the United Kingdom a SME is a business with less than 250 employees). The unifying characteristic of SMEs in all countries is that they constitute 97-99 per cent of all business in any given country. The definition also comprises micro enterprises, ie enterprises that are owner-operated.

17 World Trade Organization World Trade Report 2016: Levelling the trading field for SMEs (2016); Jennifer Abel-Koch and others France, Germany, Italy, Spain and the United Kingdom: Internationalisation of European SMEs - Taking Stock and Moving Ahead (Bpifrance, British Business Bank, Cassa Depositi e Prestiti SpA, Instituto de Crédito Oficial and KfW Bankengruppe, March 2018); and OECD Meeting of the OECD Council at Ministerial Level: Paris, 7-8 June 2017 - Enhancing the Contributions of SMEs in a Global and Digitalised Economy (2017). In New Zealand only 23 per cent of SMEs trade across borders: New Zealand Ministry of Foreign Affairs \& Trade Trade and Small and Medium Enterprises.

18 The European Commission's study into intra-EU trade by SMEs found that one third of respondents felt that difficulties relating to the resolution of cross-border conflicts stifled their cross-border trade: European Commission European contract law in business-to-business transactions: Analytical Report (Flash EB Series No 320, 2011). Similarly, the World Bank and the International Finance Corporation in their 2012 copublished study reported that efficiency and transparency in dispute resolution were pivotal in encouraging cross-border trade: The World Bank and The International Finance Corporation Doing business in a more transparent world: Comparing regulation for domestic firms in 183 economies (2012). See also the result of the New Zealand and Austrian research into the contractual behaviour of SMEs that found that for at least 50 per cent of SMEs the uncertainty of dispute resolution is a consideration whether to trade cross-border: Petra Butler and Christina Geissler "Contractual Realities of SMEs - Access to Commercial Justice" in Klausegger Christian and others (eds) 2020 Austrian Yearbook on International Arbitration (Manz, Stämpfli Verlag and $\mathrm{CH}$ Beck) at 92, 96 and 97 (forthcoming).

19 Commonwealth Heads of Government, above n 14. 
investment will allow Commonwealth countries to reduce poverty and to work towards SDG $1 .{ }^{20}$ One important cornerstone of attracting foreign direct investment is the provision of, what foreign investors perceive to be, a neutral, efficient and enforceable dispute resolution mechanism should a dispute with a local business arise. ${ }^{21}$ The World Bank in its 2012 study of 100 economies found that, where the alternative dispute resolution legal framework is not strong, this is perceived as an obstacle to foreign direct investment. ${ }^{22}$

In summary, the uncertainty about the resolution of disputes creates a barrier to cross-border trade and investment. This is highlighted in the current environment where the World Trade Organisation has estimated that "world merchandise trade could decline between $13 \%$ and $32 \%$ in 2020 ". ${ }^{23}$ The Commonwealth therefore needs to establish a robust modern cross-border dispute resolution framework to eliminate any uncertainties regarding cross-border dispute resolution, to help the Commonwealth countries' resilience framework and to stimulate economic growth and ultimately to reduce poverty in the Commonwealth.

The burgeoning intra-Commonwealth trade and the dynamics of the Commonwealth trade in general require a cross-border dispute resolution regime which allows parties to adequately manage their dispute resolution risk. Greater economic benefits will be gained and barriers to trade reduced where both inter and extra Commonwealth trading partners are assured that their disputes will be efficiently handled, and dispute settlements easily enforced. This is particularly important in a time of major disruption such as COVID-19. ${ }^{24}$ At this point in time international commercial arbitration offers the best cross-border dispute resolution regime not only due to the advantages stated earlier but also due to the flexibility it has shown regarding the COVID-19 disruption. ${ }^{25}$ Above all SMEs will benefit from a comprehensive international commercial arbitration regime. SMEs are the engines of economic growth particularly for developing Commonwealth countries since SMEs decentralise

20 United Nations "Goal 1: "End poverty in all its forms everywhere" <www.un.org/sustainabledevelopment>.

21 Sophie Pouget Arbitrating and Mediating Disputes: Benchmarking Arbitration and Mediation Regimes for Commercial Disputes Related to Foreign Direct Investment (Word Bank Policy Research Working Paper No $6632,2013)$ at 4 and 5.

22 Pouget, above n 21, at 3. Commonwealth countries were incorporated in the study: Australia, Bangladesh, Brunei Darussalam, Cameroon, Canada, Cyprus, Ghana, India, Kenya, Malaysia, Mauritius, Mozambique, New Zealand, Nigeria, Pakistan, Papua New Guinea, Rwanda, Sierra Leone, Singapore, Solomon Islands, South Africa, Sri Lanka, Tanzania, Uganda, United Kingdom and Zambia.

23 World Trade Organization "WTO goods barometer flashes red as COVID-19 disrupts world trade" (20 May 2020) <www.wto.org>.

24 See Patricia Scotland "We must leverage the 'Commonwealth Advantage' to counter the economic fallout of COVID-19" (27 April 2020) <https://thecommonwealth.org>.

25 See Maxi Scherer "Remote Hearings in International Arbitration: An Analytical Framework" (2020) 37 J Int'1 Arb (forthcoming). 
wealth more equitably compared with larger industries and often provide women, in particular, with a source of income. ${ }^{26}$

\section{CHALLENGES}

Does the Commonwealth provide a unified international commercial arbitration framework? For Commonwealth businesses, in particular SMEs, to take advantage of the "Commonwealth advantage" it is important that they can rely on a best practice international commercial arbitration framework within the Commonwealth.

The Commonwealth countries' international commercial arbitration frameworks are characterised by a significant disparity across the 54 jurisdictions ${ }^{27}$ despite the shared heritage and the continuous engagement of Commonwealth jurisdictions through the Commonwealth Secretariat. This disparity is on the one hand a challenge in itself, but on the other hand it holds considerable opportunity. Regarding the latter, opportunity or advantage lies in that there are Commonwealth countries that provide models for a successful international commercial arbitration framework. The disparity allows for critically evaluating and rethinking certain aspects of the existing international commercial arbitration paradigms. Challenges exist in particular regarding the effectiveness of the legislative framework applicable to arbitration, the familiarity with arbitration among users and the legal profession, the quality of the arbitrators, the diversity amongst arbitrators and counsel, the cost of international commercial arbitration, regulatory considerations and the use of technology.

\section{A Effectiveness of the Legislative Framework}

Some member jurisdictions have what is generally understood as a fully developed arbitration practice: modern arbitration legislations, strong arbitral institutional practice, signatories to the Convention on the Recognition and Enforcement of Foreign Arbitral Awards 1958 (the New York Convention ${ }^{28}$ and arbitration friendly courts. However, 58 per cent of Commonwealth jurisdictions have an arbitral framework that does not respond adequately to the demands of cross-border trade. Those jurisdictions are at risk of losing foreign direct investment and trade revenue by not making a modern dispute resolution regime available to their country's business community. Their business environment therefore lacks an important resilience component.

26 OECD Small Businesses, Job Creation and Growth: Facts, Obstacles and Best Practices.

27 The Commonwealth is comprised of 53 countries. However, for the purposes of the Study the United Kingdom was counted as the jurisdictions of England, Wales and Northern Ireland and Scotland.

28 The Convention on the Recognition and Enforcement of Foreign Arbitral Awards 1958330 UNTS 3 (signed 10 June 1958, entered into force 7 June 1959) [New York Convention]. 
Those 58 per cent of Commonwealth jurisdictions still rely on arbitration statutes modelled on the Arbitration Act 1889 (UK) or the Arbitration Act 1950 (UK) ${ }^{29}$ or do not have any legal framework for international commercial arbitration at all. ${ }^{30}$ Unsurprisingly, the 1889 and 1950 Acts contain provisions that are not in line with modern commercial arbitration best practice. ${ }^{31}$ The Acts also lack provisions on the power of an arbitral tribunal to determine its jurisdiction and the doctrine of separability, ${ }^{32}$ which are cardinal principles of arbitration today and are widely accepted. ${ }^{33}$ Further, the Acts are inconsistent with the requirements of the New York Convention. The New York Convention in turn has not been acceded to by 15 countries - or 28 per cent of Commonwealth jurisdictions.

Arbitral legislation that does not conform to current best practice does not necessarily lead to a hostile arbitral framework. ${ }^{34}$ However, it does pose a greater risk that modern best practises are ignored and that the perception of a jurisdiction's arbitration friendliness and suitability for modern arbitration practice suffers and deters foreign direct investment. In addition, a dated arbitral framework does not prepare a country's businesses for partaking in cross-border trade and poses a considerable trade barrier.

29 Including Antigua and Barbuda, Belize, Botswana, Cameroon, Dominica, Gambia, Grenada, Guyana, the Kingdom of Eswatini (previously Swaziland), Kiribati, Lesotho, Malawi, Namibia, Nauru, Pakistan, Papua New Guinea, Saint Lucia, Samoa, Seychelles, Sierra Leone, Solomon Islands, St Vincent and the Grenadines, Tanzania, Trinidad and Tobago and Tuvalu.

30 Overall, five Commonwealth countries' arbitration acts are modelled on the Arbitration Act 1889 (UK) 52 \& 53 Vict c 49, 14 on the Arbitration Act 1950 (UK), five countries have arbitration legislation based on arbitration Acts predating 1977 and two countries do not have any arbitration legislation.

31 For example legislation based on the Arbitration Act 1889 (UK) uses language which does not resonate anymore in today's international arbitration discourse; an arbitration agreement is referred to as a "submission" and arbitrators are referred to as "umpires" in the arbitral process: Arbitration Act 1904 (Eswatini), Commonwealth Conciliation and Arbitration Act 1904 (Cth), s 8; Arbitration Act 1988 (Dominica), s 10; and Arbitration Act 1989 (Grenada), s 8.

32 See UNCITRAL Model Law on International Commercial Arbitration 1985, With amendments as adopted in 2006 (UN Doc A/40/17 annex I and A/61/17 annex II, 7 July 2006) [UNCITRAL Model Law], art 16.

33 See Born, above n 10, at 350-353 and 1047-1051.

34 Some Caribbean Countries have demonstrated that trained and experienced judges in international commercial arbitration can overcome legal challenges based on arbitration principles recognised by common law. That is the case of Antigua and Barbuda and Dominica, whose decisions are subject to the Eastern Caribbean Supreme Court. Although the arbitral legislation of both countries is still based on the Arbitration Act 1950 (UK), the two countries presented few, but good examples of pro-arbitration court decisions: see VT Leaseco Ltd v Fast Ferry Leasing Ltd ECSC HC ANUHCV 0312/2005, 13 July 2007; Canisby Limited v Flat Point Development Limited ESCS CA ANUHCVAP2016/0005, 13 February 2017; and Calais Shipholding Co v Brown Energy Trading Ltd ECSC HC DOMHCV2009/0096, 9 March 2012. 
The need for a modern international commercial arbitration framework that reflects best practice was also recognised by respondents to the surveys in the Study. As one Oceanian Government emphasised in its response:

The revision and update of the current legal framework for arbitration by ratifying the New York Convention and by the domestication of a new arbitration bill based on the Model Law or appropriate model legislation that is appropriate for the country [is one of the most pressing issues regarding international arbitration in the country].

Similarly, one of the respondent judges urged: ${ }^{35}$

Nineteen commonwealth countries are not members of the New York Convention. This means only $65 \%$ of Commonwealth countries can take full advantage of international arbitration. This needs to be a priority led by the Commonwealth.

Therefore the need to have a state of the art international commercial arbitration regime, where all Commonwealth jurisdictions are a member state of the New York Convention and have a modern arbitration law, ${ }^{36}$ was an important concern expressed in the responses to the arbitrator, counsel and academic surveys. ${ }^{37}$

\section{B Familiarity with Arbitration Among Users and the Legal Profession}

There is no doubt that multinationals and large businesses are familiar with international commercial arbitration and are regular users. In fact the Queen Mary University of London School of International Arbitration has conducted several international arbitration surveys ${ }^{38}$ that show the rise

35 Recently a number of Commonwealth countries have acceded to the New York Convention, above n 28, such as Papua New Guinea and Seychelles, which explains the judge's numbers.

36 The benchmark for a modern arbitration law is UNCITRAL Model Law, above n 32.

37 For 27 per cent of arbitrators having a state of the art international commercial arbitration regime was one of the most pressing issues to the success of international arbitration in the Commonwealth after education and capacity building ( 39 per cent), it was one of the most pressing issues for the Commonwealth for six per cent of counsel (for 12 per cent it was costs, followed by education and capacity building at 10 per cent and recognition and enforcement at eight per cent) and for seven per cent of academics who identified education and capacity building as the most pressing issue ( 28 per cent), followed by costs (eight per cent).

38 According to the Queen Mary survey methodology the respondents were comprised of the following groups: academics, arbitral institutions, arbitrators, "arbitrator and counsel in equal proportion", expert witnesses, inhouse counsel, and private practitioners. 12 per cent were categorised as "other" (such as judges, third funders and government officials). It is noteworthy that the business voice is only represented through in-house counsel which suggests that only large businesses and multinationals have been part of the survey. In addition, in-house counsel do not necessarily represent the thinking of management in its entirety. It also should be noted that in-house counsel only represented a small percentage of respondents, for instance 10 per cent in the 2018 Study. 
of popularity of international commercial arbitration among large businesses and multinationals. ${ }^{39} \mathrm{In}$ the 2018 Queen Mary Study 97 per cent of respondents indicated that international arbitration is their preferred method of dispute resolution. ${ }^{40}$ This result proves a remarkable increase from the finding in 2006, where 73 per cent of respondents stated that their preferred method is international arbitration. ${ }^{41}$ In the commodity trade and under maritime and insurance contracts arbitration is the mandated dispute resolution mechanism. ${ }^{42}$ There are also certain industries where international commercial arbitration tends to be the preferred cross-border dispute resolution mechanism. ${ }^{43}$

By contrast, however, SMEs which make up approximately 97 per cent of businesses in any given country, often do not take advantage of international commercial arbitration. Responses to the Study business survey and data collected by the international research group that studies the contractual behaviour of SMEs suggest that SMEs are generally less familiar with international commercial arbitration as a method of dispute resolution. ${ }^{44}$ The survey results are a clear reminder that there is a difference in contractual behaviour, including dispute resolution behaviour and preference, between SMEs and large businesses. SMEs build their business relationship on trust and honesty. Those qualities are more important than the revenue stream the business partner represents. However, 72 per cent of businesses that responded to the Study survey had a single written contract document and 88 per cent acknowledged that they did think about what could go wrong in a cross-border contractual relationship. Qualitative research undertaken in New Zealand ${ }^{45}$ found that only 64 per cent of SMEs

39 See PricewaterhouseCoopers and Queen Mary University of London School of International Arbitration International arbitration: corporate attitudes and practices 2006 (2006) [2006 QM Study]; Pwc and Queen Mary University of London School of International Arbitration Corporate choices in International Arbitration: Industry perspectives (2013) [2013 QM Study]; Pinsent Masons and Queen Mary University of London School of International Arbitration Pre-empting and Resolving Technology, Media and Telecoms Disputes: International Dispute Resolution Survey (2016) [2016 QM Study]; and 2018 QM Study, above n 6.

40 Either on a stand-alone basis (48 per cent) or in conjunction with alternative dispute resolution (ADR) (49 per cent): see the 2018 QM Study, above n 6, at 5.

41 See the 2006 QM Study, above n 39, at 5.

42 Michael Collet "Maritime Arbitration" in Julian DM Lew and others (eds) Arbitration in England with chapters on Scotland and Ireland (Wolters Kluwer, Alphen aan den Rijn (The Netherlands), 2013) 145.

43 See for example regarding construction Pinsent Mason and Queen Mary University of London School of International Arbitration Survey - Driving Efficiency in International Contract Disputes (2019).

44 Regarding the research group see MSME Justice <www.msmejustice.com>. Regarding publications see Butler and Geissler, above n 18; and Petra Butler and Hanneke van Oeveren SMEs and International Commercial Dispute Resolution: Without leading the horse to water, it's unlikely that it will drink (UNCITRAL) (forthcoming).

45 The research was undertaken between 2015 (pilot) and 2018. 45 SMEs and four large companies were interviewed. SMEs in New Zealand are defined as businesses with less than 70 employees: above n 16. Geographically the companies were distributed throughout New Zealand and they operated in the agricultural (in particular honey and wine); manufacturing (from biscuits to specialised high-tech products); distribution; 
have one single contract document. Moreover, only 35 per cent of Spanish SMEs always had a formal written contract document and 50 per cent of Spanish SMEs stated that they have never signed a contract. ${ }^{46} 15$ per cent of Spanish SMEs stated that they occasionally sign a contract when either the other party requires it or if there are special circumstances that require a formal written contract. Ancillary contractual documents, such as order forms, bill of ladings and letter of credits are only used by 50 per cent of the respondents to the Study survey whereas 90 per cent of Spanish SMEs acknowledged that they use order forms or pro-forma invoices.

24 per cent of respondents can demand full payment before delivery. Internet banking is the preferred method of payment. Businesses, especially smaller businesses, that responded to the Study survey identified with not having had a dispute with one of their overseas trading partners (53 per cent). In New Zealand the number is even higher: 78 per cent of businesses had never engaged in a "formal" dispute resolution process. ${ }^{47}$ Negotiation is the preferred method of dispute resolution, meaning SMEs try to amicably resolve their dispute, according to the business respondents to the Study survey. ${ }^{48}$ This finding is corroborated by the New Zealand research. On the other hand, only 25 per cent of Spanish SMEs resort to negotiation if a dispute arises, while 40 per cent of Spanish SMEs resort to court proceedings. SMEs interviewed for the New Zealand Study had lucky escapes

sale of goods (in particular timber); and service sectors. The research was undertaken by Georgia Whelan, solicitor, Chapman Tripp, Hanneke van Oeveren, solicitor, Kensington Swan and Dr Petra Butler.

46 The research was undertaken by Dr Cayetana Santaolalla, Professor University of Mondragon. The research was undertaken between February and May 2019 and comprised 38 SMEs and two large businesses. Regionally, six SMEs (all wine export) came from Alava; six SMEs (wine export, food, manufacturer) came from Navarra; 26 SMEs (eight wine export, eight food companies, four footwear companies, four construction companies, two engineering companies) came from La Rioja. The two large businesses were located in Navarra and had between 400 and 500 employees. The definition of a SMEs is less than 250 workers.

47 Looking to Australia the findings are similar: Australian Small Business and Family Enterprise Ombudsman Access to Justice: Where do Small Businesses go? (November 2018) at 14 found that 78 per cent of Australian small businesses did not have a dispute in the last year. The Australian Ombudsman survey indicated that as business size increases, businesses face a higher incidence of disagreements. Larger businesses - in Australia those employing more than 19 people or with revenues greater than AUS 3 million - face nearly double the number of disagreements compared to sole traders (those with revenue of less than AUD 250,000). When disagreements occurred, only 42 per cent of sole traders sought advice, compared to 75 per cent of larger businesses. For the majority of disagreements, larger businesses (67 per cent) were able to resolve the dispute without escalating it to a formal process, compared to the overall average of 41 per cent.

4829 per cent of respondents stated that they would negotiate if their business partner failed to carry out their obligation(s), 24 per cent would cancel the contract and 24 per cent would invoke the dispute resolution clause in the contract. A survey by the Australian Small Business and Family Enterprise Ombudsman, above n 47, at 6 and 9 found that: "The first thing 9 out of 10 businesses did was to speak with the other party to try and resolve the dispute" and that one in three disputes were not escalated through a formal process because it was possible to resolve the dispute another way (41 per cent); or the expected costs were considered to be more than the potential gain (15 per cent); or the business did not have time to follow up the dispute (11 per cent). The Australian Ombudsman survey does not distinguish between domestic and cross-border disputes and only four per cent of respondents reported a dispute with a foreign business. 
- they were either able to settle their disputes before or during a cross-border litigation or they were able to walk away from the business relationship without losing their business and chose to never trade with a business from that country again. Others were wary of making a foray into foreign markets: for over 50 per cent of New Zealand, Spanish, and Austrian ${ }^{49}$ SMEs and 88 per cent of survey respondents, dispute resolution concerns were an issue when venturing into a foreign market. This corroborates the findings of the World Bank/IMF and European Commission studies. ${ }^{50}$ Otherwise they spent considerable time and money on finding out about their prospective foreign business partner. ${ }^{51}$

\section{Quality of Arbitrators}

Feedback received in responses to the counsel and arbitral institution questionnaires and voiced in the interviews conducted indicate there is some concern amongst respondents over the quality of arbitrators. ${ }^{52}$ The concern regarding arbitrator quality highlights that with any adjudicatory system, the efficacy and legitimacy of international arbitration ultimately depends on the quality of the decision-making. If parties are not satisfied with the quality of their arbitrators, it follows that they will be unlikely to continue using arbitration to resolve their disputes. As members of the judiciary in some jurisdictions indicated in their survey response, ineffective arbitrators can also hinder the overall development of international arbitration.

Reasons for the (perceived) lack of arbitrator quality can be multiplex and complex. The lack of familiarity with international commercial arbitration of counsel might lead to the appointment of just the "wrong" arbitrator for the case. Some arbitrators might lack the necessary knowledge of the subject matter and familiarity with the relevant legal systems necessary.

49 The research has been undertaken by Christina Geissler, University of Linz, and involved 15 SMEs from different sectors mainly from the Linz region.

50 The World Bank and The International Finance Corporation, above n 18; and European Commission, above n 18.

5152 per cent of survey respondents reported that they would visit their prospective business partner before contracting, a finding corroborated by especially New Zealand SMEs where a number have stated that they even have invited a prospective business partner and their family to a holiday in New Zealand to meet them and to establish a relationship of trust.

52 The quality of arbitrators was expressed by between $2-5$ per cent of respondents to the arbitrator and counsel survey respectively in respect of the Commonwealth and globally and was voiced strongly in a number of interviews from interviewees located in Oceania, London and the Caribbean particularly. The significance of the empirical finding is that the concern of the quality of arbitrators was a common and constant concern. It also has to be noted that given that the surveys asked the respondents to nominate freely, ie there was no list to choose from, the three most pressing issues in their home jurisdiction, the Commonwealth and globally that any statistical ascertainable value is noteworthy. Even in the sub-group of Indian counsel where the quality of arbitrators was the second most identified concern together with the availability of arbitrators, only 13 per cent of counsel identified quality as an issue. 


\section{Diversity Amongst Arbitrators and Counsel}

A lack of gender, ethnic and geographical diversity is a concern for the professional international arbitration community. ${ }^{53}$ The Study also indicates an increasing concern over a lack of professional diversity vis-a-vis the participation of non-lawyers as party representatives and arbitrators. ${ }^{54}$ Lack of diversity is also closely linked to the issue of expertise and familiarity. ${ }^{55}$

However, only four per cent of the respondent counsel survey believed that diversity was an issue that needed to be resolved on a national level and merely five per cent of respondents thought that it needed to be resolved within the Commonwealth. ${ }^{56}$ Of the female respondents (who represented 37 per cent of the total counsel respondent pool), only five per cent identified diversity as a major concern in the Commonwealth. ${ }^{57}$ At the international level, diversity was perceived as a more important issue with eight per cent of counsel listing it as one of the three most pressing issues. However, for female counsel, diversity was the most pressing issue on the global stage ( 25 per cent). ${ }^{58}$

Arbitrators identified the diversity and widening of the arbitrator pool third equal with costs as the most pressing issue for the Commonwealth and third equal with the issue of interference of the judiciary in arbitral proceedings globally. Hence, for arbitrators themselves, a diverse pool, including gender, geographical representation but also subject matter expertise, was more important than for

53 See Jacomijn van Haersolte-van Hof "Diversity in Diversity" in Albert Jan van den Berg (eds) Legitimacy: Myths, Realities, Challenges (Wolters Kluwer, Alphen aan den Rijn (The Netherlands), 2015) 638; Susan D Franck and others "The Diversity Challenge: Exploring the 'Invisible College' of International Arbitration" (2014) 53 Colum J Transnat'l L 429; and Samaa A Haridi "Towards Greater Gender and Ethnic Diversity in International Arbitration" (2015) 2 BCDR International Arbitration Review 305.

54 For instance, one interviewee from the commodity and trade sector identified a growing emphasis on lawyers and legal qualifications in arbitration as hindering the role of non-lawyers in the field. This concern is exacerbated by regulations in some jurisdictions, like India, that impose strict qualification requirements on arbitrators, including familiarity with aspects of Indian law. See also Indian Arbitration and Conciliation (Amendment) Act 2019, sch 8.

55 See Gemma Anderson, Richard Jerman and Sampaguita Tarrant "Diversity in International Arbitration" (2019) Thomson Reuters Practical Law <https://uk.practicallaw.thomsonreuters.com>.

56 The make-up of the respondents to counsel questionnaire was 37 per cent women and the majority of respondents were between 25-34 years old. Geographical respondents represented the Commonwealth: from the Caribbean to Malaysia, from New Zealand to the United Kingdom. Since the survey allowed free flowing answers it has to be noted that the majority of answers regarding diversity did not distinguish between gender diversity, ethnic or age diversity. Some African respondents mentioned in particular the participation of African lawyers in international arbitration or the lack thereof.

57 Female counsel identified the three most pressing issues that needed to be resolved to strengthen international arbitration in their respective countries as awareness raising (10 per cent), a supportive, non-interventionist judiciary (nine per cent) and suitable laws (eight per cent).

58 Diversity was followed by costs (12 per cent) and the application of common and uniform rules and standards (eight per cent). 
counsel. This result is particularly noteworthy since the respondents to the arbitrator survey were predominantly male ( 80 per cent) and the majority were between $65-74$ years old.$^{59}$

A lack of diverse "quality" arbitrators is problematic for several reasons. Most importantly, a tribunal that does not reflect the geographical and cultural makeup of the parties is arguably in danger of being less likely and able to give due weight to those geographical or cultural factors that might have informed the parties' dealings.

The Study survey also linked the lack of diversity to the dominance of a few international arbitration hubs. Another general consensus emerged that a diverse tribunal improves the overall quality of the decision-making process. ${ }^{60}$

\section{E Cost Considerations in Arbitration}

The responses to the surveys conducted as part of the Study indicated that costs are among the most pressing issues facing international arbitration globally and in the Commonwealth. For 10 per cent of the respondents' arbitrators, costs, equal with issues related to diversity, were one of the pressing issues in the Commonwealth. Whereas 24 per cent of arbitrators identified capacity building in all its forms (including education and awareness) as one of the pressing issues followed by the need for law reform (17 per cent), only four per cent of arbitrators found that time was a pressing issue in the Commonwealth. ${ }^{61}$ Four per cent of counsel identified costs as a pressing international arbitration issue in their respective country, eight per cent regarding the Commonwealth (capacity building and a functioning institution were of greater concern than costs) and 13 per cent globally. Time or delay on the other hand was not identified as a comparatively major issue by respondents in either the arbitrator nor the counsel surveys.

High costs in arbitration, apart from raising practical concerns, also implicate the right of access to arbitration, ${ }^{62}$ which in certain circumstances can amount to a denial of access to justice. ${ }^{63} \mathrm{~A}$ way to remedy such a problem is the provision of assistance in bearing the costs of arbitral proceedings. All Commonwealth jurisdictions provide some form of legal assistance and/or legal aid. However, it

5931 per cent of arbitrators were between 65-74 years old, followed by respondents in the 45-54 year old bracket (23 per cent). Nine per cent of respondents were over 75 years old.

60 See generally Linda Peach "We need women on boards for many reasons: ethics isn't one" (20 February 2015) The Conversation <https://theconversation.com>.

61 Seven per cent of arbitrators identified costs as a pressing issue in their respective countries and globally, costs was one of the most pressing issues for 12 per cent.

62 David AR Williams and John Walton "Costs and Access to International Arbitration" (2014) 80 Arbitration: The International Journal of Arbitration, Mediation and Dispute Management 432.

63 Butler and Herbert, above n 10, at 206. Compare Anna McNee Legal Expenses Insurance and Access to Justice (International Bar Association, 2019). 
is generally unclear whether legal assistance extends to businesses and/or alternative dispute resolution mechanisms. ${ }^{64}$ Third party funding, contingency fee agreements, ${ }^{65}$ and before and after the event, legal cost insurance, ${ }^{66}$ are other options open to businesses to fund an international commercial arbitration claim. ${ }^{67}$ As far as information could be ascertained, none of these funding possibilities is available all over the Commonwealth. ${ }^{68}$

While costs raise valid concerns, it is worth emphasising that, on average, arbitration proceedings still tend to be perceived as more cost-efficient than litigation, especially in jurisdictions where the judicial system is overloaded. Furthermore, costs criticisms do not extend to all forms of arbitration. Indeed, some types of arbitrations are well-known for their efficient resolution of disputes. ${ }^{69}$

64 For example Australia provides initial legal advice/assistance to small businesses in all states and territories (see country report at [43] of the Study), in the Bahamas legal assistance to businesses seems to be provided through Eugene Dupuch Law School clinics (see country report [47] of the Study), Malawi's Legal Aid Bill, s 2 defines a legally aided person as a "natural or legal person" (see country report at [37] of the Study) and in Botswana, India and Namibia legal aid appears to extend to arbitration (see country reports at [39], [55] and [33] of the Study respectively). On the information available it seems that only nine per cent of Commonwealth jurisdictions extend legal aid to businesses and in 26 per cent of jurisdictions legal aid appears to cover arbitrations. However, it is unclear whether this includes international arbitration.

65 As far as information was available, contingency fee agreements are legal in at least 37 per cent and prohibited in 33 per cent of all Commonwealth jurisdictions.

66 Legal insurance is offered, according to the information available, in 38 per cent of Commonwealth jurisdictions, including, for example, Australia, England and Wales, Scotland, Cyprus and South Africa.

67 The majority of respondents to the counsel survey stated that they were aware of the different funding possibility but not had it seen operate in practice ( 56 per cent). 81 per cent of respondents to the arbitrator survey had never been an arbitrator in an arbitration where, to their knowledge, a party was funded by a thirdparty funder.

68 Even though costs were identified as one of the most pressing issues, hardly any of the responses to the survey results mention third party funding and none mention contingency fee arrangements or before or after legal cost insurance.

69 For example the London Maritime Arbitrators Association (LMAA) and the Grain and Feed Trade Association (GAFTA) arbitrations are often commended for their efficiency by users. Under the LMAA Terms 2017: "The awards should normally be available within not more than six weeks from the close of the proceedings. In many cases, and in particular where the matter is one of urgency, the interval should be substantially shorter" (at [22]). Further, hearings of up to two days should be scheduled within three months; hearings of 3-5 days should be scheduled within six months; and hearings for 6-10 days should be scheduled within 10 months. As for GAFTA arbitrations, "[t]he average time taken between 2017-2018 from the date of the timetable begin set to the date of issue was 7 months for a first-tier award and 11 months for an appeal." (Interview with commodity arbitrator, London and arbitrator with particular technical expertise, London). It should be noted that proceedings in commodity arbitration are generally conducted on the papers only. It also needs to be mentioned that under many of the commodity association rules, an appeal is possible which prolongs the timeline and adds to the costs. Article 10 of the Arbitration Rules No 125 of The Grain and Feed Trade Association (GAFTA) gives the parties a right to appeal against an award to a Board of Appeal that must be elected and constituted and must comply with the procedure established on such rules. As well, art 7 


\section{F Regulatory Considerations}

A jurisdiction's regulatory design even if not directly related to international commercial arbitration can nevertheless have an undesirable impact on commercial arbitration frameworks. Regulatory measures that negatively impact the use of international commercial arbitration as the preferred form of cross-border dispute resolution includes the ability to instruct foreign counsel to assist with the proceedings, ${ }^{70}$ the ability and ease for participants of an arbitration to obtain a visa and the ease of tax matters. The survey results suggest that the additional resource strain to obtain visa and taxation approvals is seen by some arbitrators and counsel as one of the pressing issues facing the Commonwealth and is an issue globally. In particular, arbitration specialists have alluded to the prohibitive nature of visa and taxation approvals in the interviews conducted for the Study. ${ }^{71}$ However, 76 per cent of the respondent arbitrators to the survey reported that they do not encounter any prohibitive regulatory measures.

\section{G Use of Technology}

The Commonwealth Connectivity Agenda includes digital connectivity recognising the differences in digital connectedness within the Commonwealth and the need for all Commonwealth countries to be digitally connected. ${ }^{72}$ The disruption of cross-border trade due to COVID-19 has amplified the necessity for Commonwealth countries to have good digital connectedness. The use of technology in international commercial arbitration has the potential to reduce a substantial number of inefficiencies within the process, while facilitating greater access to dispute resolution services in a more cost-effective way ${ }^{73}$ and reducing international arbitration's carbon footprint. ${ }^{74}$ Alexander Fessas, Secretary-General of the ICC International Court of Arbitration, identified four stages of an

of the Rules of Arbitration and Appeal of the Federation of Oils, Seeds and Fats Associations Ltd (FOSFA), gives the parties the right to appeal an award of arbitration to a Board of Appeal.

70 Born, above n 10, at 2840 .

71 Especially arbitrators from Asia, Africa and Oceania.

72 Efforts undertaken in line with the Commonwealth Connectivity Agenda, above n 14, will help to address the challenges identified. If countries embark on the formulation of a digitisation policy, it will be important to keep the issues related to international dispute resolution technology in mind.

73 See Maxi Scherer "Artificial Intelligence and Legal Decision-Making: The Wide Open?" (2019) 36 J Int'l Arb 539. Indeed, 26 per cent of survey respondents stated that technology will have a crucial impact on international commercial arbitration, 38 per cent saw it as having a role in aiding arbitral proceedings and 14 per cent believed that it would destroy the "charm" of international arbitration.

74 See UNCITRAL Technical Notes on Online Dispute Resolution (New York, 2017), adopted by UNCITRAL at its forty-ninth session in 2016: Online dispute resolution for cross-border electronic commerce transactions" Technical Notes on Online Dispute Resolution (UN Doc A/CN.9/888, 11 April 2016). See also the green pledge for international arbitration by Lucy Greenwood: Greenwood Arbitration <www.greenwoodarbitration.com>. 
arbitration proceeding where technology can be useful: communications, storage of documents, research tools and hearing logistics. ${ }^{75}$

Based on the survey results, technology is to some degree prevalent in both litigation and arbitration within the Commonwealth. ${ }^{76}$ The use of technology in arbitration fares slightly better than in litigation. ${ }^{77}$ Over half of the respondent arbitrators used video conferencing and hearing room technology 1-5 times last year. However, virtual hearing rooms are a rarity. In addition, artificial intelligence appears less prevalent in international commercial arbitration. The use of video conferencing, hearing room technology and virtual hearing rooms by counsel mirrors that of arbitrators. ${ }^{78}$ There does, however, appear to be greater use of artificial intelligence by counsel in case management: 27 per cent report having used artificial intelligence to aid their cases in the past year. The majority of counsel use cloud-based storage. Respondent arbitral institutions that have hearing premises all offer video conferencing and hearing room technology. The most recently inaugurated arbitral institutions that responded to the survey also possess virtual hearing room technology.

The use of technology does not come without challenges: (i) arguably most importantly, the meaningful use of technology assumes technological literacy by the stakeholders; ${ }^{79}$ (ii) stakeholders may also have insufficient access to the required technology; and (iii) depending on the sophistication

75 Pratyush Panjwani The Present and Near Future of New Technologies in Arbitration: If not Us, Who? If not Now, When? (2018) 33 Spain Arbitration Review 21 at 28.

76 All eight stakeholder surveys asked about the use of technology in aid of dispute resolution, for example the use of email, video conferencing, the availability of hearing room technology (multimedia presentation facilities and real time electronic transcripts), the use of virtual hearing rooms, the use of artificial intelligence; and e-filing.

77 In litigation, email is recognised as a means of communication in all courts of the respondent judges and is used by half of the courts to file documents. One third of the courts are equipped with video conferencing technology that allows parties and experts to present multimedia presentations (although a majority of respondent judges also reported that in the past year, the video conferencing facilities offered had not been used). 63 per cent of all respondent judges stated that their civil procedure codes (or equivalent) allow parties to introduce evidence based on artificial intelligence. In addition, 31 per cent of the judges indicated that artificial intelligence (for example data analytics and technology assisted document review) had been used 15 times in their court in the last year. In sum, while the use of technology is formally recognised and permitted in a range of ways in the litigation context, it appears to be underutilised by parties.

78 Over 50 per cent have used those services $1-5$ times in the last year.

7988 per cent of the respondent businesses use the internet in particular to find a new business partner and/or to acquire information; "to check out" their new potential business partner through their websites (48 per cent). However, that does not mean that they would feel able or comfortable to use IT-based processes in an international dispute resolution; 57 per cent of New Zealand SMEs and only 35 per cent of Austrian SMEs stated that they would feel comfortable to use technology to help them settle their disputes. 
and vulnerability of the technology available, there could be concerns in securing the confidentiality and privacy of communications.

The Commonwealth's Connectivity Agenda has identified the need for equal digitisation within the Commonwealth. This will be necessary so that the use of technology to aid international commercial arbitration can be utilised equally throughout the Commonwealth. In a second step the Commonwealth needs to identify ways to harness the benefits of technology in providing more effective dispute resolution systems, whether in arbitration or litigation. ${ }^{80}$

\section{SOLUTIONS}

The Commonwealth, due to its unique position as a group of countries based on a Grundnorm of common heritage, is well placed to find modern future-orientated solutions to the challenges posed. However, this requires the Commonwealth to ameliorate the challenges which exist due to the disparity in the stage of international commercial arbitration development.

\section{A Robust Modern International Arbitration Framework}

One of the foremost initiatives the Commonwealth has to undertake is to aid all its member countries to adopt a robust, modern international commercial arbitration framework that incorporates best practices. This entails supporting all Commonwealth countries to accede to the New York Convention and pass enabling legislation, and to adopt a modern arbitration law based on the UNCITRAL Model Law on International Commercial Arbitration 2006. ${ }^{81}$ By adopting the 2006 Model Law, Commonwealth jurisdictions can be assured that their international arbitration legislation is modern and effective. They also benefit from the growing body of authority from other jurisdictions interpreting and implementing the provisions of the Model Law. ${ }^{82}$ This is a clear benefit for both domestic and international commercial parties, who will have more certainty in the application of a Model Law based arbitration legislation by being able to rely on considerable precedent and academic literature. In addition, adopting the 2006 Model Law assures potential foreign investors that the national courts will recognise and enforce an agreement to resolve disputes through arbitration, which can be an important consideration in assessing whether to invest.

For the Commonwealth to be at the forefront of providing for a best practice international commercial arbitration framework it should encourage its members to adopt amendments and additions to the 2006 Model Law which reflect the development of international commercial arbitration in the last 15 years. Those include, for example:

80 Only one of the respondent Governments had a digitalisation policy.

81 UNCITRAL Model Law, above n 32.

82 See UNCITRAL Model Law, above n 32, art 2A; and Born, above n 10, at 1631. 
- $\quad$ the selection of the definition of "arbitration agreement" in accordance with art 7, Option 1 Model Law;

- the inclusion of emergency arbitrators to the definition of "arbitral tribunal";

- the adoption of additional provisions on the role of the court in referring or rejecting requests that claims be submitted to arbitration;

- the adoption of additional provisions that permit a challenged arbitrator to withdraw from office and clarify when the mandate of a challenged arbitrator terminates;

- a provision that sets out the confidentiality and privacy obligations of the parties;

- a provision that sets out the liability and immunity of arbitrators;

- $\quad$ appointing authorities and arbitral institution; and

- a provision concerning legal representation in arbitral proceedings.

\section{B Capacity Building and Awareness Raising}

Given the Commonwealth's generally shared history, the general reliance on the common law and the widespread use of English among the legal profession and users of international commercial arbitration, the Commonwealth provides a supportive environment to build international commercial arbitration capacity for all stakeholders. ${ }^{83}$

In order to address the issue of capacity building and lack of awareness of international commercial arbitration, Commonwealth jurisdictions need to support and facilitate the implementation of programmes to familiarise and assist in capacity building of their judiciaries, legal professions and universities. Member jurisdictions should highlight the importance of universities, law societies, bar councils and business communities in building capacity for international commercial arbitration. In particular, member jurisdictions should make information regarding best practice in cross-border contracting, the benefits of different international dispute resolution mechanisms, policy papers and legislation and regulations in connection to arbitration readily available on specific websites. Additionally, capacity and awareness surrounding the use of technology in aiding international dispute resolution within Commonwealth legal communities needs to be increased.

\section{Enhancing Diversity}

There is a need to address the lack of diversity within the international arbitration community. Commonwealth jurisdictions need to be aware of the challenges regarding diversity in international commercial arbitration and should send a clear signal to their law societies, bar councils, and arbitral institutions by requiring transparent diversity reporting. This requires eliminating the general barriers

83 Austrian SMEs have stated that their attitude towards contracting with German SMEs was different than with other contract partners within the EU, suggesting that language and historical ties play a role in B2B relationships. This suggests that the Commonwealth is the ideal supportive environment for businesses to experience international commercial arbitration. 
restricting equal access including (but not limited to) financial barriers, social class, lack of flexibility, a culture of exclusivity and unconscious bias. ${ }^{84}$ Additionally, certain arbitration-specific barriers also need to be addressed, including a lack of easily accessible information on diverse candidates, a lack of dialogue in certain regions, a lack of visibility of diverse candidates, a lack of diversity statistics and weak internal processes for ensuring diversity appointments and hiring. ${ }^{85}$ Member jurisdictions should cooperate with their law societies, bar councils, and arbitral institutions in order to foster diversity in international arbitration. Member jurisdictions involved in international commercial arbitrations should consider diversity as a factor in making their arbitral appointments. Further, arbitral institutions and other reporting authorities should be encouraged to report statistics on their appointment practices each year. This approach is apparent in the practice of the leading arbitral institutions which include diversity data in their annual reports. These institutions have shown marked improvements in their approaches to diversity in recent years. The ICC, for instance, reported that in 2018 the number of female arbitrator appointments in ICC proceedings more than doubled between 2015 to 2018 from 136 to 273 . Moreover 35 per cent of the arbitrators it appointed were also below the age of $50{ }^{86}$ In geographical terms, the ICC also appointed arbitrators from over 87 jurisdictions, which was a new record. ${ }^{87}$ Statistics from other leadings institutions - the Arbitration Institute of the Stockholm Chamber of Commerce (SCC), Singapore International Arbitration Centre (SIAC) and Hong Kong International Arbitration Centre (HKIAC) - reflect similar trends. ${ }^{88}$ A diversity pledge should also be considered by Commonwealth jurisdictions in order to support capacity building and diversification efforts.

\section{Enhancing Cost Efficiency}

Commonwealth jurisdictions should consider taking several legislative steps to improve cost efficiency within international commercial arbitration. Jurisdictions should consider amending their arbitration law to provide that any award shall be made within a certain time frame unless parties agree otherwise. Access to international commercial arbitration for indigent parties should be ensured through repealing the doctrines of champerty and maintenance for international commercial arbitration at a minimum to allow third party funding; allowing contingency fee agreements; encouraging before the event legal cost insurance; and by making legal aid available for international commercial arbitration and including businesses in the eligible group of legal recipients. Awareness

84 Rosaline Sullivan Barriers to the Legal Profession (Legal Services Board, July 2010).

85 Anderson, Jerman and Tarrant, above n 55.

86 ICC Dispute Resolution 2018 Statistics (ICC Publication No 898E, 11 June 2019) at 11 and 12.

87 At 4

88 Arbitration Institute of the Stockholm Chamber of Commerce "SCC Statistics 2018" <https://sccinstitute.com/statistics>; Singapore International Arbitration Centre Annual Report 2018 (2019); and HKIAC "2019 Statistics" (2019) <www.hkiac.org/about-us/statistics>. 
needs to be increased and parties should be encouraged to make use of trade association, ad hoc arbitrations and institutional arbitrations mechanisms for the resolution of disputes.

\section{E Regulatory Changes}

To remedy the regulatory concerns expressed by a number of arbitrators, Commonwealth jurisdictions should consider permitting the participation of foreign counsel in international arbitration seated in their jurisdictions and enhancing the existing tax frameworks and visa restrictions applicable to arbitrations and foreign counsel that participate in international commercial arbitrations in their jurisdictions. A unified arbitration friendly regulatory environment would set the Commonwealth apart and would enhance the use of international commercial arbitration as a dispute resolution mechanism within the Commonwealth but also attract non-Commonwealth parties and arbitration specialists.

\section{F Mechanisms to Facilitate Cross-Border Arbitration}

The Commonwealth is in a position where it can overcome many of the challenges discussed by facilitating the flow of information and resources through the enhancement and facilitation of international commercial arbitration within its own unique ecosystem. Developed countries and large businesses possess the knowledge and resources to avoid expensive international litigation and small state and small enterprises have limited access to finance and to the latest technologies and information on general international standards. Overcoming these problems by providing a more efficient dispute resolution system for parties by facilitating international arbitration across borders is one of the main challenges identified by the Study.

Member jurisdictions should consider developing a digitisation strategy which includes not only infrastructure but also ensuring that all stakeholders have access to technology and the capacity to use such technology. An arbitral institution noted in response to the Sudy that, "[p]arties do not know enough about online dispute resolution, and which form it may take in practice to trust it will lead to an adequate resolution of their dispute." Online dispute resolution should be facilitated in order to promote time and cost-efficient cross border disputes.

Developing a cross-border dispute resolution scheme for business-to-business (B2B) disputes based on international commercial arbitration for the Commonwealth and smaller regions is an important mechanism. 76 per cent of judges, 51 per cent of arbitrators and 51 per cent of counsel indicated a preference for a specialised $\mathrm{B} 2 \mathrm{~B}$ cross-border dispute resolution regime. There is also considerable support from arbitral institutions for such a regime (41 per cent). B2B arbitration agreements could benefit jurisdictions as they are cost-effective, have the potential to increase trade throughout the Commonwealth and also benefit small states and SMEs.

The establishment of a Commonwealth Association of Arbitral Institutions and Organisations could also be considered as a mechanism to facilitate cross-border arbitration. Such an association could serve as a platform for the exchange and development of best practices in international 
commercial arbitration. The association would also be able to foster interactions between other organisations and associations engaged in arbitration and provide a medium through which arbitration institutions can work together to build capacity and develop best practices and guidelines.

\section{CONCLUSION}

The Commonwealth, due to its distinctive environment, has the potential to create a unique international commercial arbitration framework that draws on its different cultures, different knowledge bases and often subtly different developments in the common law. This framework will be an important part of the economic resilience structure of Commonwealth countries. The challenge that it needs to overcome is to ensure that all its members boast a modern international commercial arbitration framework and, as the COVID-19 disruption has shown, to have state of the art connectivity.

Countries which have to catch up regarding a best practice international arbitration framework and capacity building of their judiciary, their legal profession, and their policy advisers will have to garner the support of the countries that already at the forefront of international commercial arbitration development. They should seek the support of institutions that are already providing training and training programmes around the world, such as the Chartered Institute of Arbitrators or the International Council for Commercial Arbitration. Importantly, international commercial arbitration has to be released from its potentially self-imposed echo chamber and has to be part of the mainstream law as well as business conference cycle to inform those who not even know what they do not know. 